\title{
The Effects of Blended Learning on the Intrinsic Motivation of Thai EFL Students
}

\author{
Usaporn Sucaromana ${ }^{1}$ \\ ${ }^{1}$ Department of Western Languages, Faculty of Humanities, Srinakharinwirot University, Thailand \\ Correspondence: Usaporn Sucaromana, Faculty of Humanities, Srinakharinwirot University, Sukhumvit 23 Rd., \\ Bangkok 10110, Thailand. Tel: 66-2-649-5545. E-mail: usaporn@swu.ac.th
}

\author{
Received: March 26, 2013 Accepted: April 12, 2013 Online Published: April 17, 2013 \\ doi:10.5539/elt.v6n5p141 URL: http://dx.doi.org/10.5539/elt.v6n5p141
}

The research is financed by Faculty of Humanities, Srinakharinwirot University.

\begin{abstract}
The aim of this study is to compare the results of blended learning with face-to-face learning among university students studying English as a foreign language. The participants were separated by gender, and the following variables, intrinsic motivation for learning English, attitudes towards English as a subject, and satisfaction with the learning climate, which was either a blended learning environment or a face-to-face learning environment, were analysed. The participants of this research are bachelor's degree students enrolled in English courses. The two class samples were drawn at random. The first class was the control group, and the other was the experimental group. The experimental group was taught using blended learning, and the control group was taught using face-to-face learning. The results of the research did not differ by gender. The students had significantly higher levels of intrinsic motivation for learning English, a better attitude towards English as a subject, and better satisfaction with the learning climate after they were taught by blended learning. Finally, the students who were taught using blended learning had significantly higher levels of intrinsic motivation for learning English and a better attitude towards English as a subject, as well as greater satisfaction with the learning climate than the students who were taught using face-to-face learning.
\end{abstract}

Keywords: blended learning, intrinsic motivation, attitudes, satisfaction, learning climate, face-to-face learning

\section{Introduction}

Progress in computer and communication systems has enabled the world to become a global society that is interconnected by the internet. The internet has been useful and has had a positive effect on education systems both the educational establishments and the students they serve (Vijitsriphiboon, 2006). Olapiriyakul and Scher (2006) state that students can have new experiences as resources are combined; the combination of resources allows for more flexibility and additional options for access to information. The internet allows a student to access information in ways that fit his/her lifestyle, and the student's learning becomes more effective (Vijitsriphiboon, 2006). Universities can offer a larger variety of options for students and can use their academic resources more effectively. Many universities use the internet for services, including library research for academic resources, and offer courses with different learning modes. Students are becoming more welcoming of internet technology in the education system, allowing for an ease of access to information and flexibility in the scheduling of courses (Waidee, 2003). As a result of this change in teaching and learning styles, the internet has reduced the use of traditional classroom teaching and replaced it with more effective systems, using programs such as Moodle and ATutor to manage classes.

The use of the internet at the university level and its integration with traditional in-class methods can enhance the learning experience of the student in acquiring, for example, English skills. English classes are designed in such a way that theory and practice prepare the students to use the language outside the classroom and to keep and apply the knowledge in different contexts. The downside of traditional language learning is that the students lack motivation due to their learning environment, where they are not involved in their learning. To address this issue, researchers have attempted to integrate technology into the classroom to allow for more variety to motivate student engagement. Students can be more active, be part of a more interesting learning environment, and 
develop intrinsic motivation for learning English, attitudes towards English as a subject, and satisfaction with the learning climate. With these possibilities in mind, the researcher has created a management system to observe the effect of blended learning on students' intrinsic motivation for learning English, attitudes towards English as a subject, and satisfaction with the learning climate.

\section{Purpose of the Research}

The research aimed to determine whether the blended learning integrated into an English course effected changes in students' intrinsic motivation for learning English, attitudes towards English as a subject, and satisfaction with the learning climate. The research objectives, which form the focus of the study, are as follows:

1) To compare the results of blended learning versus face-to-face learning among university students studying English as a foreign language, separating the students by gender,

2) To compare intrinsic motivation for learning English, attitudes towards English as a subject, and satisfaction with the learning climate before and after having blended learning in the English classes,

3) To compare intrinsic motivation for learning English, attitudes towards English as a subject, and satisfaction with the learning climate between the groups of students who experienced blended learning and the students who experienced only face-to-face learning.

\section{Literature Review}

Motivation has been defined by academics as a state of desire to initiate or to satisfy a need or desire. The psychological definition refers to the initiation, direction, intensity and persistence of behaviour towards a need. Gardner (1985) states that for education, motivation is the extent to which a person's work is based on an initial desire to do it and a satisfaction attained from the activities. A learner's drive to create and keep the intention and goal-seeking act can be referred to as motivation (Ames \& Ames, 1989). Therefore, motivation is an important aspect of learning, as it defines the extent of a student's involvement in learning, originating with his/her wish to achieve a goal and the effort he/she is willing to put forth to achieve it.

Motivation is considered an important part of both acquiring and retaining a new language, as it determines how involved the student is personally and actively (Oxford \& Shearin, 1994). Academics have defined motivation in the context of language retention as the learner's orientation toward the goal of language learning (Crookes \& Schmidt, 1991; Norris-Holt, 2001). Academics have distinguished between motivation related to reasons and motivation related to goals.

A well-known theory of motivation distinguishes between intrinsic and extrinsic motivation. As Ryan and Deci (2000) define it, intrinsic motivation is "doing something because it is inherently interesting or enjoyable", whereas extrinsic motivation is "doing something because it leads to a separable outcome". Pintrich and Schunk (2002, cited in Carreira, 2005, pp. 39-40), said that intrinsic motivation is the "motivation to engage in an activity for its own sake", whereas extrinsic motivation is the "motivation to engage in an activity as a means to an end".

Due to the variety in types of motivation and learning styles of students, educators have become interested in blended learning. Blended learning can be described as a method of learning based on the combination of online learning and face-to-face learning. Blended learning combines the best practices found in traditional teaching with the best practices of modern internet usage in learning. The pedagogy includes some technological aspects to increase effectiveness of teaching and learning (Hinterberger, Fassle, \& Bauer-Messer, 2004). Certain challenges are addressed through these non-traditional methods, such as students' need for constant focus and reinforcement from an actual professor, without which they get behind in the course (Rovai \& Jordan, 2004).

Distance learning can suffer from a lack of face-to-face instruction; blended learning has been adopted as an alternative. Dodero, Fernandez, and Sanz (2003) believe that blended learning generates more activity from the students compared to an online-only system. Additionally, traditional face-to-face teaching has started to adopt online activities to add to the classroom experience. Higher institutions have tried to adopt blended learning for the type of students and teachers who may prefer to substitute some face-to-face teaching and learning with online activities.

This new learning method combining traditional and online learning benefits full-time students as well as those who work full-time and need to travel to the university. Garrison and Kunuka (2004) discuss the new environment of the blended class: learning face-to-face and interacting with other students and teachers through e-learning. Blended learning is a design that brings the best of face-to-face and online teaching together (Dodero, et al., 2003; Garrison \& Kanuka, 2004) to best benefit the students: dividing the time between both modes and 
course designs of classes.

Information systems and technology have become quite important in educational development and have caused great change in certain systems designed for learning. The demands of students are more effectively met with the use of technology; learning processes more easily fit the lives of students and create the most ideal learning environment, creating learning groups where students may share their experiences, opinions, and understanding. The traditional classroom could be transformed into a virtual room that allows for more flexibility, reflecting the modern world and ease of communication, and for some students a reduced reliance on travel. Given these possibilities, it is worth researching the potential impact of blended learning on students' intrinsic motivation for learning English, attitudes towards English as a subject, and satisfaction with the learning climate.

\section{Methodology}

\subsection{Research Design}

This is an experimental piece of research using Randomized Control Group Pretest- Posttest Design. A survey study with quantitative data was used to gather baseline information on each group's level of intrinsic motivation for learning English, attitudes towards English as a subject, and satisfaction with the learning climate.

\subsection{Population and Participants}

The study population consisted of 267 Thai EFL students, aged 19-21, enrolling in English classes. They are bachelor's degree students and were studying English at least three days a week. Each student was randomly assigned to classes. One of the classes was randomly selected as the control group, and the other class was the experimental group. The experimental group, which received the treatment, was called blended learning, and the control group was called face-to-face learning.

Students were assigned a class using a random method called Cluster Random Sampling. The 2 classes (experimental and control) were then chosen using Simple Random Sampling, by randomly drawing a class for 1 control group and 1 experimental group. The experimental group was taught using blended learning and the control group was taught using face-to-face learning.

\subsection{Instruments}

The instruments used for this study were a pre-test and a post-test. The pre-test was used to find out whether these two groups were in the same level. Afterward, the post-test was used to detect the progress of the experimental group. The materials used for the collection of data can be separated into the following categories: (a) Intrinsic motivation for learning English survey, (b) Attitudes towards English as a subject survey, and (c) Satisfaction with the learning climate survey.

1. The intrinsic motivation for learning English survey was adapted from Chuchom, Sucaromana, and Chuawallee (1999). The survey consists of statements related to the desire or satisfaction that people wish to express. Something attracts these people to a career (such as career interest, new career, challenging career), and it can be desirable even without benefits. The intrinsic motivation for learning English survey can be divided into five sections:

1). The "desire for a challenge" section is intended to find out what career someone wants to do. That career has to be suitable to their capabilities.

2). The "interest and enjoyment" section is to find out if there is enthusiasm, happiness, or satisfaction in the career, interest or hobby.

3). The "self-confidence" section is intended to identify a person who is creative and independent in thinking and acting.

4). The "desire for ability" section is intended to identify a person who wants to be able to efficiently manage a classroom environment and wants to learn and develop their skills.

5). The "intention" section is intended to identify people who are willing to do a job using their ability without seeking any special benefits. Becoming successful in performing their ability is more important to the person than are other benefits.

In the intrinsic motivation for learning English survey, there are 20 statements with five levels of evaluation: strongly agree, agree, undecided, disagree, and strongly disagree. Each student chooses one answer for each statement. This form consists of 17 positive statements and 3 negative statements. Each positive statement is given a score based on 5 levels $(5,4,3,2$, and 1$)$ and the points for negative sentences are 5 levels $(1,2,3,4$, and $5)$, corresponding to the 5 responses: strongly agree, agree, undecided, disagree, and strongly disagree, 
respectively. The student who earns the highest score has high levels of intrinsic motivation for learning English. The survey was found that the internal consistency reliability by using coefficient alpha was .81 .

2. The survey on the attitudes towards English as a subject consists of statements relating to the student's attitude towards English as a subject. There are 10 statements in this survey with 5 levels of evaluation: strongly agree, agree, not sure, disagree and strongly disagree. Students choose one answer for each statement. This form consists of 5 positive statements and 5 negative statements. Each positive statement is given a score based on 5 levels $(5,4,3,2$, and 1$)$ and the points for negative sentences are 5 levels $(1,2,3,4$, and 5$)$, corresponding to the 5 responses: strongly agree, agree, undecided, disagree, and strongly disagree, respectively. The students who earn the highest score have a better attitude toward English as a subject. The survey was found that the internal consistency reliability by using coefficient alpha was .78.

3. The survey on the satisfaction with the learning climate consists of statements relating to satisfaction in atmosphere in English class. There are 10 statements on this form, and each consists of 5 levels of evaluation: strongly agree, agree, undecided, disagree, and strongly disagree. Students choose one answer for each statement. The points given for each statement of the 5 levels $-5,4,3,2$, and 1 - correspond to strongly agree, agree, undecided, disagree, and strongly disagree, respectively. The students who earn the highest score are highly satisfied with the learning climate in the English class. The survey was found that the internal consistency reliability by using coefficient alpha was .91 .

\subsection{Data Collection}

The researcher conducted the test in the following order:

1. Pre-test: The research participants-including the control group and the experimental group-were administered the 3 surveys.

2. The researcher taught the experimental group using blended teaching, which consists of lectures mixed with online (ATutor) teaching. This method of teaching allows students to review the lecture even when they miss the class. In addition, the researcher taught the control group using face-to-face teaching, which consists only of live lectures.

3. The research participants, including the control group and the experimental group, complete the same survey that was given pre-test; the score for this second round of surveys is considered the post-test. Then, the researcher analysed the scores obtained before and after testing both groups, using a statistical method for hypothesis testing.

\subsection{Data Analysis}

1. To compare the results by gender of the blended learning for bachelor's degree students studying English, using t-test.

2. To compare the pre-test and post-test intrinsic motivation for learning English, attitudes towards English as a subject, and satisfaction with the learning climate for both groups, using a t-test.

3. To compare the experimental group and control group students' intrinsic motivation for learning English, attitudes towards English as a subject and satisfaction with the learning climate, using a t-test.

\section{Result and Discussion}

Cronbach's alpha coefficient for the full-scale measure was used to assess the reliability of the questionnaires related to intrinsic motivation for learning English, attitudes towards English as a subject, and satisfaction with the learning climate. Table 1 indicates the reliability of the questionnaires.

Table 1. Reliability of the questionnaires related to intrinsic motivation for learning English, attitudes towards English as a subject, and satisfaction with the learning climate

\begin{tabular}{ll}
\hline Questionnaires & Cronbach Alpha Coefficient \\
\hline Intrinsic motivation for learning English & .81 \\
Attitudes towards English as a subject & .78 \\
Satisfaction with the learning climate & .91 \\
\hline
\end{tabular}

As shown in Table 1, the reliability of the full-scale questionnaires related to intrinsic motivation for learning English, attitudes towards English as a subject, and satisfaction with the learning climate is high $(.81, .78$, and .91 , respectively). In addition, the initial analysis of the data involved investigating the relationships between responses to each of the questionnaires. The Pearson correlation matrix for each of the scales is presented in Table 2. 
Table 2. Correlation of the pre- and post-test questionnaires related to intrinsic motivation for learning English, attitudes towards English as a subject, and satisfaction with the learning climate

\begin{tabular}{|c|c|c|c|c|c|c|c|}
\hline & Questionnaires & 1 & 2 & 3 & 4 & 5 & 6 \\
\hline \multirow[t]{3}{*}{ Pre-test } & 1. Intrinsic motivation & 1 & & & & & \\
\hline & 2. Attitudes towards learning English & $.56^{*}$ & 1 & & & & \\
\hline & 3. Satisfaction with the learning climate & .08 & -.03 & 1 & & & \\
\hline \multirow[t]{3}{*}{ Post-test } & 4. Intrinsic motivation & $61 *$ & $27^{*}$ & $.09^{--}$ & 1 & & \\
\hline & 5. Attitudes towards learning English & $.49 *$ & $.70 *$ & $.19 *$ & $.68 *$ & 1 & \\
\hline & 6. Satisfaction with the learning climate & $30 *$ & .24 & .26 & $.74 *$ & $.66^{*}$ & 1 \\
\hline
\end{tabular}

Note: $*=$ coefficients are significant at $p<.01$

As presented in Table 2, pre- and post-test scores on the intrinsic motivation for learning English survey are significantly correlated $(p<.01)$, as are the pre- and post-test scores on the attitudes towards English as a subject questionnaire $(p<.01)$. However, pre- and post-test scores on the satisfaction with the learning climate questionnaire were not found to be significantly correlated. Upon closer examination of the pre-test scores, intrinsic motivation for learning English and attitudes towards English as a subject are significantly correlated $(p<.01)$, but satisfaction with the learning climate significantly correlated with either intrinsic motivation for learning English or attitudes towards English as a subject. However, the post-test scores indicate that all measures are significantly correlated.

Fifty university students enrolled in an English course completed a questionnaire incorporating basic demographic information. Three demographic features are noteworthy. First, approximately $72 \%$ of the sample (36 participants) was female. Second, the participants' average age was 19.26 (SD = .56). Third, all the participants indicated that they know how to use the internet. The results of the blended learning for bachelor's degree students studying English separated by gender are shown in Table 3.

Table 3. Comparison of the results separated by gender

\begin{tabular}{|c|c|c|c|c|c|}
\hline \multirow{3}{*}{$\begin{array}{l}\text { The result of } \\
\text { blended learning }\end{array}$} & \multicolumn{4}{|c|}{ Gender } & \multirow{3}{*}{$t$} \\
\hline & \multicolumn{2}{|c|}{ Male } & \multicolumn{2}{|c|}{ Female } & \\
\hline & $\mathrm{M}$ & S.D. & $\mathrm{M}$ & S.D. & \\
\hline score & 76.33 & 5.10 & 75.09 & 8.38 & .34 \\
\hline
\end{tabular}

Table 3 shows that, after being taught by blended learning, male and female students of the experimental group showed no significant difference in their scores.

The results comparing intrinsic motivation for learning English and attitudes towards English as a subject, as well as the satisfaction with the learning climate of students being taught in blended learning and face-to-face learning methods, before and after class are presented in Table 4.

Table 4. Comparison of the difference between the experimental group and the control group during pre-test and post-test

\begin{tabular}{|c|c|c|c|c|}
\hline Group & & $\mathrm{M}$ & S.D. & $\mathrm{t}$ \\
\hline \multicolumn{5}{|l|}{ Experimental group } \\
\hline \multirow[t]{2}{*}{ Intrinsic motivation for learning English } & Pre-test & 3.91 & .25 & \multirow[t]{2}{*}{$-9.57 * * *$} \\
\hline & Post-test & 4.53 & .23 & \\
\hline \multirow[t]{2}{*}{ Attitude towards English as a subject } & Pre-test & 3.83 & .36 & \multirow[t]{2}{*}{$-6.10 * * *$} \\
\hline & Post-test & 4.37 & .31 & \\
\hline \multirow[t]{2}{*}{ satisfaction with the learning climate } & Pre-test & 3.99 & .65 & \multirow[t]{2}{*}{$-4.89 * * *$} \\
\hline & Post-test & 4.72 & .25 & \\
\hline \multicolumn{5}{|l|}{ Control group } \\
\hline \multirow[t]{2}{*}{ Intrinsic motivation for learning English } & Pre-test & 3.81 & .35 & \multirow[t]{2}{*}{-.53} \\
\hline & Post-test & 3.86 & .35 & \\
\hline \multirow[t]{2}{*}{ Attitude towards English as a subject } & Pre-test & 3.86 & .48 & \multirow[t]{2}{*}{-.51} \\
\hline & Post-test & 3.93 & .47 & \\
\hline \multirow[t]{2}{*}{ satisfaction with the learning climate } & Pre-test & 3.82 & .34 & \multirow[t]{2}{*}{-1.25} \\
\hline & Post-test & 3.94 & .39 & \\
\hline
\end{tabular}


Table 4 shows the differences between the experimental group and control group during the pre-test and post-test, and the mean score of intrinsic motivation for learning English, attitudes towards English as a subject and satisfaction with learning climate. In the control group, students scored no differently during the pre-test and post-test in intrinsic motivation for learning English, attitudes towards English as a subject, and satisfaction with the learning climate. In the experimental group, students during post-test had a significantly higher mean score of intrinsic motivation for learning English and attitudes towards English as a subject, as well as satisfaction with the learning climate compared to their pre-test scores $(p>.001)$.

The results comparing the experimental group to the control group on intrinsic motivation for learning English, attitudes towards English as a subject, and satisfaction with the learning climate are illustrated in Table 5.

Table 5. Comparison of the difference between the experimental group's and the control group's mean score of intrinsic motivation for learning English, attitudes towards English as a subject, and the satisfaction with the learning climate

\begin{tabular}{|c|c|c|c|c|}
\hline & Group & $\mathrm{M}$ & S.D. & $\mathrm{t}$ \\
\hline \multirow{3}{*}{$\begin{array}{l}\text { Pre-test } \\
\text { Intrinsic motivation for learning }\end{array}$} & & & & \\
\hline & Experimental & 3.91 & .25 & 1.15 \\
\hline & Control & 3.81 & .35 & \\
\hline \multirow[t]{2}{*}{ Attitude towards learning English } & Experimental & 3.83 & .36 & -.232 \\
\hline & Control & 3.86 & .48 & \\
\hline \multirow[t]{2}{*}{ satisfaction with the learning climate } & Experimental & 3.99 & .65 & 1.17 \\
\hline & Control & 3.82 & .34 & \\
\hline \multicolumn{5}{|l|}{ Post-test } \\
\hline \multirow[t]{2}{*}{ Intrinsic motivation for learning } & Experimental & 4.53 & .23 & $8.00 * * *$ \\
\hline & Control & 3.86 & .35 & \\
\hline \multirow[t]{2}{*}{ Attitude towards learning English } & Experimental & 4.37 & .31 & $3.88 * * *$ \\
\hline & Control & 3.93 & .47 & \\
\hline \multirow[t]{2}{*}{ satisfaction with the learning climate } & Experimental & 4.72 & .25 & $8.48 * * *$ \\
\hline & Control & 3.94 & .39 & \\
\hline
\end{tabular}

$* * * p<.001$

Table 5 shows the mean scores on intrinsic motivation for learning English, attitudes towards English as a subject, and satisfaction with the learning climate for the experimental group and the control group. In the pre-test, both students from the experimental group and control group had no significant difference in mean score for intrinsic motivation for learning English, attitudes towards English as a subject, and satisfaction with the learning climate. In addition, in the post-test, the experimental group's mean score was significantly higher $(p>.001)$ than the control group's mean score for intrinsic motivation for learning English and attitudes towards English as a subject, as well as satisfaction with the learning climate. That means students who studied in a blended learning environment gained higher results than students who studied in face-to-face learning environments.

\section{Conclusion and Recommendations for Further Studies}

Blended learning consists of lectures mixed with online teaching. This method of teaching allows students to review lectures online if they should ever be absent. This study compares the results of blended learning among bachelor's degree students studying English, separated by gender, and compared intrinsic motivation for learning English, attitudes towards English as a subject and satisfaction with the learning climate before and after class in the blended learning and face-to-face learning environments. The results of this research showed that the results of blended learning do not differ by gender. That means blended learning in studying English as a foreign language can be used for teaching both males and females. The results of this research, in addition, showed that students had significantly higher intrinsic motivation for learning English and attitudes towards English as a subject, as well higher satisfaction with the learning climate after they were taught using blended learning. It would be beneficial to study the results of blended learning as they affect other variables, such as patience in learning English and responsibility, etc. Additionally, testing a comparison between blended teaching and other teaching methods would help improve or develop future teaching methods and other researchers should try to teach using blended teaching with other subjects besides English.

\section{Reference}

Ames, C., \& Ames, R. (1989). Research in motivation in education. San Diego: Academic Press.

Carreira, J. M. (2005). New framework of intrinsic/extrinsic and integrative/instrumental motivation in second 
language acquisition. The Keiai Journal of International Studies, 16, 39-64.

Crookes, G., \& Schmidt, R. W. (1991). Motivation: Reopening the research agenda. Language Learning, 41, 469-512. http://dx.doi.org/10.1111/j.1467-1770.1991.tb00690.x

Dodero, J. M., Fernández, C., \& Sanz, D. (2003). An experience on students' participation in blended vs. online styles of learning. SIGCSE Bulletin, 35(4), 39-42. http://dx.doi.org/10.1145/960492.960522

Gardner, R. C. (1985). Social psychology and second language learning: The role of attitudes and motivation. London: Edward Arnold.

Garrison, R., \& Kanuka, H. (2004). Blended learning: Uncovering its transformative potential in higher education. Internet and Higher Education, 7, 95-105. http://dx.doi.org/10.1016/j.iheduc.2004.02.001

Hinterberger, H., Fässler, L., \& Bauer-Messer, B. (2004). From hybrid courses to blended learning: A case study. In International Conference on New Educational Environments (ICNEE) Switzerland: University of Neuchatel.

Norris-Holt, J. (2001). Motivation as a contributing factor in second language acquisition. The Internet TESL Journal, 7, 1-6.

Olapiriyakul, K., \& Scher, J. M. (2006). A guide to establishing hybrid learning courses: Employing information technology to create a new learning experience, and a case study. The Internet and Higher Education, 9(4), 287-311. http://dx.doi.org/10.1016/j.iheduc.2006.08.001

Oxford, R. L., \& Shearin, J. (1994). Language learning motivation: expanding the theoretical framework. Modern Language Journal, 78, 12-28. http://dx.doi.org/10.1111/j.1540-4781.1994.tb02011.x

Rovai, A. P., \& Jordan, H. M. (2004). Blended learning and sense of community: A comparative analysis with traditional and fully online graduate courses. International Review of Research in Open and Distance Learning, 5(2). Retrieved from http://www.irrodl.org/index.php/irrodl/article/view/192/795

Ryan, R. M., \& Deci, E. L. (2000). Self-determination theory and the facilitation of intrinsic motivation, social $\begin{array}{llll}\text { development, and } \quad \text { well-being. American } & \text { Psychologist, }\end{array}$ http://dx.doi.org/10.1037/0003-066X.55.1.68

Vijitsriphiboon, P. (2006). A construction and efficiency validation of a web-based instruction (WBI) program on computer architecture 1 for bachelor degree of Rajamanagala Institute of Technology (RIT). Unpublished master's thesis, King Mongkut's Institute of Technology North Bangkok, Bangkok, Thailand.

Waidee, T. (2003). A development of computer assisted instruction on computer network system and data communication fundamental for information technology for life. Unpublished master's thesis, King Mongkut's Institute of Technology Ladkrabang, Bangkok, Thailand. 